The Lakehead University Forestry Association held its fourth annual symposium earlier this year. The topic, Production Potential and Management of Under Utilized Species, turned out to be a symposium on poplar, and proved to be very exciting, interesting and informative.

Mr. J. McLaughlin, from Morbark Industries, discussed the total chip concept of harvesting hardwoods. The entire tree is chipped and the green, brown and white chips are sorted in a portable debarker-chipper-sorter. With the aid of a movie, Mr. McLaughlin showed the operation in 1970 of the Morbark "Super Beaver" in experimental hardwood plots in Minnesota.

The cost analysis from the experiment showed an initial equipment cost of $\$ 473,650$ including the Super Beaver, a Drott fellerbuncher, two grapple skidders, a portable sorting screen and maintenance over a five year period. In the same period at 300 tons per day production (400 tons maximum) the cost per ton of chips would be $\$ 4.79$ delivered to the mill. The idea that greater utilization can lower the cost of harvesting was stressed.

Mr. Art Ennis of Boise Cascade talked about a tree length chip operation used by Boise Cascade, International Falls, Minnesota. He stressed that their operation was under very specific conditions. Three separate contracts have been let out for different aspects of the operation. Thus one contractor is responsible for cutting and limbing the trees and delivering them to the chipping site in time for the wood to cure before it is chipped. This contract made up one-third of the total cost of the chips. The second contractor is responsible for the running of the Morbark 2250 Chipper and Debarker purchased by Boise Cascade in 1968, and for loading the chips into semitrailer vans. Mr. Ennis stated that the Morbark 2250 was $93 \%$ operational compared to down time, but that the maintenance crew worked after hours to keep the machine in order. Production was 18,000 cords per year per shift. This portion of the opera-
DAVID REID and GARY MCKELLAR, who will be in Lakehead's first graduating class, describe

\section{Lakehead's symposium}

tion incurred $16 \%$ of the cost. The third contract was for hauling the chips from the site to the mill using eight $40 \mathrm{ft}$ company owned semi-trailer vans with an extra one at the chipper, and four leased tractor units. The average haul was 80 miles with a load of 10 to 12 cords depending on moisture content. Loading time was approximately one hour. Twenty-seven percent of the total chip cost occurred here.

$\mathrm{Mr}$. Ennis suggested that separate contracts and a piecework pay system got everyone working as a team and the result was better economically than other systems of chipping. He concluded his talk by stating that presently $61 \%$ of the wood required in Minnesota is filled by chips; that this could rise to $83 \%$ in the future; and that Boise Cascade would probably purchase another chipping machine.

Dr. F. Bender, formerly of the Eastern Forest Products Laboratory in Ottawa, was the next speaker. Dr. Bender was involved in a program to study the use of wood sawdust and chips as a food stuff for cattle and other animals with four-part stomachs. time immemorial but its low digestibility in untreated form prevented its use as a continuous diet. Dr. Bender found through his experiments that poplar had the best untreated digestibility $(15 \%)$ of the woods he tested. $\mathrm{He}$ stated that $40 \%$ digestibility was required to sustain stock and that $45 \%$ enabled daily weight gain. By subjecting the poplar sawdust or chips to steam pressure of 10 to 15 atmospheres, acetic acid is produced which breaks down to cellulose and ligin and increases the digestibility to $48-52$ percent. A small amount of ammonia is passed over the chips. This reacts with acetic acid to produce a nitrogenous compound that equals protein in nutritional value.

He stated that sawdust has been used as a bulk food from the

The next speaker Mr. A. Sudbury spoke on potential domestic and international markets for Canadian wood-based panels. $\mathrm{He}$ stated that Canada was presently fifth in production capacity of wood-based panels. Mr. Sudbury noted that a $20 \%$ tariff on Canadian plywood exports allows the USA to import $87 \%$ of its hardwood plywood from Asia at cheaper cost. The US industrial plywood market is now filled by Finland and Japan, but could be partly filled by Canadian products through better marketing techniques which stress the quality and competitive prices of Canadian goods.

Mr. Sudbury suggested we could obtain a greater part of the European market for panels by demonstrating the variability and versatility of such products to potential buyers. Canada's 1971 export of wood based panels totalled $\$ 34,000,000$ and the chance of new markets looks good.

The last speaker was $\mathrm{Dr}$. L. Zufa from Ontario's Ministry of Natural Resources Research Centre at Maple. Dr. Zufa has done much research into the genetic improvement of poplars especially in hybrid production. He stated that an increase in the poplar cut was imminent as the 
allowable cut of softwoods approaches the maximum. He emphasised the advantages of poplar which are short rotations, ability to grow on a variety of sites, response to fertilization and cultivation, and ease of genetic improvement. Dr. Zufa displayed charts showing improved hybrid poplars obtaining three times the diameter, three to five times the height and two to four times the mean annual increment over nat- ural poplar stands on similar sites. The hybrid $\mathbf{P}$. grandidentata $X$ P. Alba at Maple grows more than 1 inch in dbh per year and at 12 years is 14 inches in diameter. Dr. Zufa talked about 20 to 25 year rotations for veneer with 16 to 18 inch $\mathrm{dbh}$ and $80 \mathrm{ft}$ tall trees, and 5 to 10 year rotations for pulpwood.

Following a lively general question period, the over 200 attending the day's proceedings ad- journed to the main cafeteria for a bar and dinner. After dinner Mr. B. Addison spoke as a devoted environmentalist and concluded that North America should set up a workable world government to enforce the limited use of world resources, to control world population and maintain a world wide living standard. We should think, he said, of these goals in regional development schemes.

\section{Employment and the classes of '72}

Prompted by Donald James' Can I get a job?, your Editor asked the four forestry faculties with a graduating class if they could supply a breakdown of the employment status of their current graduating year. Of the 194 graduates, at least $70 \%$ appear to have a permanent type of employment. Laval had the largest graduating class, followed by UNB, Toronto and UBC. There is, perhaps, little difference in the percentage distribution of unemployment between the faculties, if some of the unknowns now have, or will soon find, employment. However, if we were to assume that all the unknowns were unemployed, the situation is the reverse of James' findings about the pessimistic east in that the percentage of unemployed decreases the further east one goes.

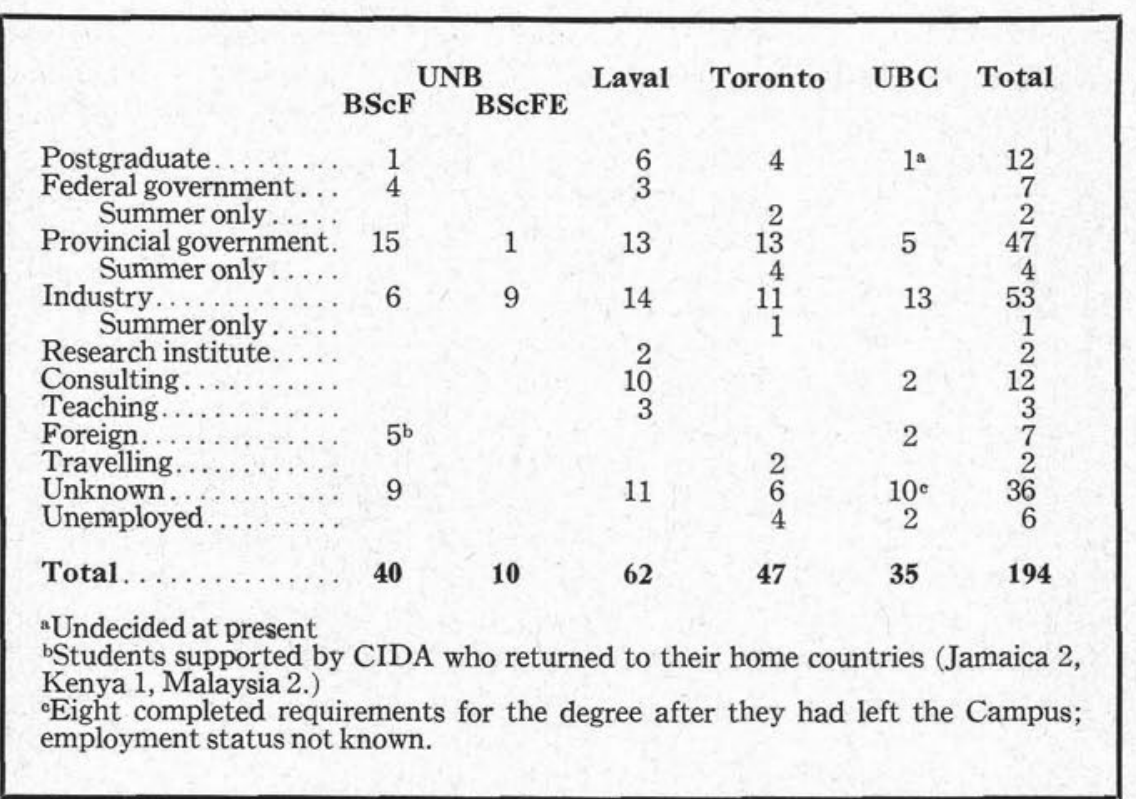

Toronto supplied some information on the employers of the graduates. Of the 13 graduates with a Provincial government, 9 were with the BCFS. This was evidently a one year increase in demand due to the opening of a new forest district plus increased activity in the reforestation and tree improvement programs. Of their 11 graduates with industry, 5 went with Proctor and Gamble who opened a new mill at Grande Prairie, Alberta. It would have been interesting to have known whether the other faculties also supplied graduates to these two employers.

Looking down the figures it will be seen that only Laval and UBC graduates entered the consulting field; Laval and UNB graduates provided the federal government with its "quota". Employment was divided equally between government and industry at $27 \%$ apiece; the three eastern faculties provided a few more to government than industry, whereas UBC provided more to industry. About $10 \%$ of the Toronto and Laval graduates will undertake postgraduate work.

We intend to provide a similar look at the situation next year. 